\title{
Bilimsel İletişimin Zamana Göre Değişimi: Bir Atıf Analizi Çalışması*
}

\author{
Changes in Scholarly Communication over Time: A Citation \\ Analysis Study
}

\author{
Nazan Özenç UÇAK ${ }^{* *}$ ve Umut $A L^{* * *}$
}

\begin{abstract}
Öz
Bu makalede bilimsel iletişimin zaman içinde gösterdiği değişim üzerinde durulmaktadır. Bu amaçla Hacettepe Üniversitesinde 1968-2007 yılları arasında sosyal bilimler, temel bilimler, mühendislik, sanat ve beşeri bilimler alanında yer alan 16 disiplinde tamamlanan tezlerin atıf analizi yapılmıştır. Tabakalı örneklemle seçilen 391 tez yıl, sayfa sayısı, atıf sayısı gibi bibliyometrik özelliklerine; bu tezlerde yer alan toplam 29.298 atıf yayın türü, yayının dili, yazar sayısı gibi özelliklerine göre incelenmiştir. Bu özelliklerin zaman içinde ne gibi farklııklar gösterdiği araştırılmıştır. Çalışmada ayrıca tezlerde yer alan atıfların dönemler itibariyle yaşlanma hızlarında bir farkııık olup olmadığına bakılmıştır. Elde edilen bulgular onar yıllık dönemler altında değerlendirilmiştir. Ayrıca, bilimsel iletişimde zaman içinde ortaya çıkan değişimin disiplinler arasında gösterdiği farklııklar farklı başlıklar altında karşılaştırılmıştır.
\end{abstract}

Anahtar sözcükler: Bilimsel iletişim, Atıf analizi, Bibliyometri, Tezler

\begin{abstract}
This paper focuses on the changes of scholarly communications throughout time. For this purpose citation analysis of the theses that belong to sixteen different disciplines from social sciences, basic science, engineering, and arts and humanities in Hacettepe
\end{abstract}

\footnotetext{
*Bu çalışma TÜBITAK Sosyal Bilimler Araşıııma Grubu (SOBAG) tarafından desteklenen "Bilimsel iletişimin zamana ve disiplinlere göre değişimi: Tezler üzerine bibliyometrik bir inceleme" başlıklı projenin (Proje no: 107K505, Proje Yöneticisi: Nazan Uçak) bir kısım verilerine dayanılarak hazırlanmıştır.

**Doç. Dr.; Hacettepe Üniversitesi Edebiyat Fakültesi Bilgi ve Belge Yönetimi Bölümü, Beytepe Ankara (ucak@hacettepe.edu.tr)

***Dr.; Hacettepe Üniversitesi Edebiyat Fakültesi Bilgi ve Belge Yönetimi Bölümü, Beytepe Ankara (umutal@ hacettepe.edu.tr)
} 
University between the years 1968 and 2007 are examined. Samples are chosen according to stratified sampling techniques. A total of 391 theses are investigated according to their bibliographical features such as year, number of pages and citations. Moreover, 29.298 citations are analyzed according to type, language, and authors of resources; while literature obsolescence is investigated according to a certain period of time. Research outputs are evaluated in groups of ten-year periods. Finally, our study compares the change that occurs in scholarly communication in time and among various disciplines.

Keywords: Scholarly communication, Citation analysis, Bibliometrics, Theses

\section{Giriş}

Bilimsel iletişim bilim insanlarının yaptıkları araştırmalar sonucu elde ettikleri bulguları sözlü ya da yazılı olarak sundukları bir süreci kapsamaktadır. Geçmişte söz konusu iletişim süreci oldukça sınırlı ortamlarda gerçekleştirilmiştir. Tarihsel açıdan bakıldığında benzer konularda çalışan araştırmacıların birbirleriyle mektuplaşmaları, soyluların gözetiminde yapılan toplantılar ya da konuya hâkim topluluklara yapılan sözlü sunumlar bilimsel iletişimin gerçekleştiği ilk ortamlar olarak dikkati çekmektedir (Carriveau, 2001, s.74). 19. yy. uygulamalı bilimlerin gelişimiyle birlikte bilimsel iletişimde yayın çeşitliliğinin; 20. yy. bilimsel araştırmanın arttığı, ulusal ve uluslararası araştırma kurumlarının geliştiği dönemler olmuştur. Özellikle gelişen bilimsel yayıncılık anlayışı ile birlikte, zaman içinde bilimsel iletişimde yeni iletişim ortamlarının kullanılmaya başlandığı bilinmektedir. Bu yüzyılda bilgisayarlar ve internet meslektaşlar arasında hızı haberleşme olanağı ile değişimi ve paylaşımı hızlandırmıştır (Vickery, 2000). Bilimsel iletişim sürecinin önemli bir parçası olan yazarlar araştırmalarına kaynaklık edecek bilgileri elektronik ortamdan sağlamaya yönelmekte, araştırma sonuçlarını yayınlama ve dağıtmada ön baskı (preprint) arşivleri, açık erişim dergileri, kişisel Web siteleri ve elektronik dergiler gibi ortamları tercih etmektedirler (Bauer ve Bakkalbasi, 2005; Borgman ve Furner, 2002). Bununla birlikte okuyucuların da zaman içinde elektronik ortamı kullanma eğiliminin arttığı görülmektedir (Anderson, Sack, Krauss ve O’Keefe, 2001; Herman, 2001). Elektronik ortamın tercih edilmesinin en önemli nedenleri arasında bilginin içeriğine hızlı erişim, güncellik, zaman ve mekândan bağımsız hareket edebilme olanağı gibi faktörler öne çıkmaktadır. Son yıllarda elektronik ortama geçişte görülen bu hızlı değişime rağmen basılı ortama olan ilginin tamamen ortadan kalkması beklenmemektedir.

Bilgi teknolojisi başta olmak üzere pek çok faktörden etkilenen bilimsel iletişim süreci zaman içinde farklılık gösterebilmektedir. Bu farklıı̆̆ın neler olduğu, bunların her disiplin için aynı şekilde gerçekleşip gerçekleşmediği bilgi merkezleri ve hizmetlerinin bu değişime uyum gösterebilmesi açısından araştırılması gereken konulardır. Bu çalışmada 40 yıllık bir dönem (1968-2007) içinde Hacettepe Üniversitesinde tamamlanan lisansüstü tezlerin kaynakçaları incelenmek suretiyle zaman içinde bilimsel iletişim sürecine yönelik olarak hangi değişimlerin yaşandığı araştırılmaktadır. 


\section{İlgili Çalışmalar}

Bilgi yönetimi alanında önemli derleme makalelerin yayımlandığı bir yayın olan Annual Review of Information Science and Technology'de bilimsel iletişim ve bibliyometri konusu ele alınarak bu konuda zaman içinde görülen gelişmeler topluca değerlendirilmiştir (Borgman ve Furner, 2002). Nitekim son yıllarda bilimsel iletişime yönelik gerçekleştirilen çalışmalarda değişim üzerine odaklanıldığı ve bu çalışmalarda veri toplarken atıf analizinden yararlanıldığı sıklıkla görülmektedir (Bauer ve Bakkalbasi, 2005; Herring, 2002; Kushkowski, 2005; Liu, 2003). Atıf analizi bilimsel araştırmaların izlenmesinde, etkilerinin ölçülmesinde, atama kararlarının alınmasında ve parasal desteklerin verilmesinde önemli bir araç olarak kullanılmaktadır (Bauer ve Bakkalbasi, 2005). Bununla birlikte atıflar zaman içinde araştırmacıların hangi kaynaklardan bilgi sağlamayı tercih ettikleri konusunda önemli bulgular sunmaktadır. Kütüphanelerin koleksiyonlarının oluşturul-masında ve ayıklanmasında da söz konusu bulgulardan büyük ölçüde yararlanılmaktadır (Sylvia, 1998, s.25). Atıf analizi çalışma-ları aynı zamanda bilimsel iletişimin bir alandan diğerine farklııı gösterdiğine ilişkin bulguları ortaya koyması açısından da önem-lidir. Nitekim bu yöntemle yapılan araştırmalarda fen bilimlerinde yapılan yayınların önemli bir kısmının bilimsel dergilerde yayım-lanan makalelerden oluştuğunu; sosyal bilimler, sanat ve insan bilimlerinde ise kitap ağırlıklı bilgi kaynağı kullanımının yoğun olduğunu göstermektedir (Al, Şahiner ve Tonta, 2006, s.1011; Tonta, 2006, s.28; Lindholm-Romantschuk ve Warner, 1996, s.391).

Farklı alanlarda bilimsel iletişimde tercih edilen yayın türlerinin zaman içinde değişimi çok kolay değildir. Bazı araştırmalar beşeri bilimlerde yayınevlerinin dergi yayıncılığına yönelmesi, kitaplara ilişkin maliyet-kâr olgusunun cazip olmaması gibi çeşitli nedenlerle bilimsel yayıncılıkta monograf üretiminin azaldığını vurgulamaktadır (Magner, 2000; Waters, 2000). Bu durumun doğru olduğu kabul edildiğinde, zaman içinde beşeri bilimlerdeki atıf yapılan kaynaklara yönelik olarak kitapların ağırlığının azalması beklenebilir. Ancak yapılan araştırmalar bunun doğru olmadığını göstermektedir. Nitekim böyle bir hipotezi test eden bir araştırmada İngiliz ve Amerikan Edebiyatı disiplinlerine yönelik atıf analizi çalışması yapılmış, sonuç itibariyle beşeri bilimler alanı için monograf türü yayınların ağırlığının ortadan kalkmasının beklenmemesi gerektiği sonucuna varılmıştır (Thompson, 2002, s.133).

Bilimsel iletişimde yaşanan değişim pek çok faktörün etkisindedir. Bunlar içinde en belirgin faktör elektronik ortamın bilimsel iletişime getirdiği yeni açılımlardır. Bu nedenle Web sayfaları, elektronik dergiler, elektronik tezler gibi özellikle elektronik ortamdaki kaynaklara yapılan atıfların çeşitli yönlerden incelendiği çalışmalara literatürde daha fazla yer verilmektedir. Bu çalışmalardan birinde basılı tezlerle elektronik tezlerdeki Web kaynaklarına yapılan atıflar analiz edilmiş, basılı tezlerde atıfların \%2,2'sinin, elektronik tezlerde atıfların \%5,4'ünün Web kaynaklarına yapılan atıflar olduğu saptanmıştır (Kushkowski, 2005, s.259). Aynı çalışmada yıldan yıla elektronik kaynaklara yapılan atıflarda genel bir artış olduğu belirtilmektedir (Kushkowski, 2005, s.268). Bilimsel iletişimde İnternet'in gelişmesine paralel olarak Web'in etkisi giderek artmaktadır. Lisans öğrencilerinin araştırma raporlarının kaynakçalarına dayalı olarak gerçekleştirilen bir 
çalışma, 1996 yılında \%9 olan Web kaynakları kullanımının 1999 yılında \%21'e ulaştığını ortaya koymaktadır (Davis ve Cohen, 2001, s.309). Bir başka çalışmada kütüphane ve bilgi bilimlerindeki elektronik dergilerin kaynakçaları incelenmiş, incelenen dokuz dergideki 1277 makaleden 1035'inde (\%81) Web kaynaklarına atıf yapıldığı saptanmıştır. 20002006 yılları arasını ele alan söz konusu çalışmada Web'deki yayınlara yapılan atıfların neredeyse basılı ortamdaki yayınlara yapılan atıflar kadar olduğu görülmektedir (Bhat ve Kumar, 2008).

Bibliyometrik çalışmalarda "eskime" kavramı herhangi bir alandaki bilimsel literatürün okunma, atıf alma ya da kullanılma oranlarının zamana bağlı olarak azalma göstereceğini ifade etmek için kullanılan bir kavramdır. Literatür eskimesi ile ilgili çok sayıda çalışma bulunmaktadır. Bu çalışmalar genellikle disiplin bazlı gerçekleştirilmektedir (örneğin, bilgisayar bilimleri - Cunningham ve Bocock, 1995; psikoloji - Sangam, 1998). Literatürün gelişmesi ile eskimesi arasında bir ilişki bulunmaktadır (Sangam, 1998, s.33). Alanda bilgi birikiminin yoğunluğu ve geriye dönük bilgi intiyacının olması eskime oranını artırmaktadır. Öte yandan literatür yaşlanması olgusunun yıllar içinde farklılık gösterip göstermediği de üzerinde çalışılan bir konu olmuştur (Glänzel ve Schoepflin, 1995).

Bilimsel literatürde araştırma konusu olarak ele alınan bir başka konu da hangi dilde yayın üretildiğidir. Bilimsel iletişimde yayının dili görünürlük, erişim ve kullanım açısından olduğu kadar alan özellikleriyle de yakından ilgilidir. İngilizcenin giderek artan düzeyde bilim dili olarak kullanılmaya başlanmasının bir sonucu olarak araştırmacılar daha fazla kişiye ulaşabilme kaygısıyla araştırma sonuçlarını kendi dillerinde yayımlamak yerine İngilizce yayımlamayı tercih etmektedirler (Casalini, 2003). Bu durum zaman içinde İngilizce konuşan ülkeler dışında kalan ülkelerin kendi dillerini bilimsel iletişim aracı olarak sınırlı düzeyde kullanmalarına sebep olmakta, bu ülkelerde bilim dilinin ana dilde gelişimi yavaşlamaktadır. Nitekim Uzun'un (1998) 1987-1996 yıllarında sosyal bilimler alanına Türkiye'den katkı sağlayan yazarlarla ilgili yapmış olduğu araştırma sonuçları bu yayınların büyük bir kısmının İngilizce olduğunu göstermektedir. Bununla birlikte yayın sayısındaki artış sınırlı da olsa yerel yayınların sayısının artmasında ve zaman içinde belli bir birikime ulaşmasında etkili olmaktadır.

Bilimsel iletişimde yayınlarda yer alan yazar sayısı alanın ekip çalışmalarına ve disiplinlerarası araştırmalara açık olup olmamasıyla yakından ilgilidir. Bu nedenle fen ve mühendislik alanında ortak yazarlı çalışma sayısı fazladır. Ancak zaman içinde disiplinlerarası oluşumun artması ortak yazarlı çalışma sayısının da artmasında etkili olmaktadır. Bu nedenle yazar sayısındaki artış ve yazar kavramının farklı algılanmaya başlanması da bilimsel iletişimdeki değişimler arasında yer almaktadır. Son yıllarda literatürde yazar sayısındaki artışın ve yazarlık kavramının sorgulandığı birçok çalışma bulunmaktadır (Al, 2005; Bates, Anić, Marušić ve Marušić, 2004; Cronin, 2001). Bilimsel iletişimde zamanla çok yazarlıığa doğru bir yönelişin olduğu geçmiş yıllarda da dile getirilen bir konudur (Clarke, 1964; Gordon, 1980). Bilim dünyasındaki ortaklaşa yayın yapma eğilimlerinin sonucu olarak çok yazarlı yayınların sayısının hızlı bir şekilde arttığı görülmektedir. 


\section{Yöntem}

$\mathrm{Bu}$ araştırmada Hacettepe Üniversitesinin farklı bölümlerinde tamamlanan lisansüstü tezlerin kaynakçaları incelenmekte ve tezlerin atıf özelliklerinin saptanmasına çalışılmaktadır. Temel araştırma sorusu, tezlerde yer alan atıfların zaman içinde farklılaşıp farklı-laşmadığıdır. Bir başka ifadeyle bu çalışmada, tezlerin kaynakçaları incelenerek atıf yapılan kaynakların zamana bağlı olarak değişiklik gösterip göstermediği, değişimin hangi alanlarda hangi özellikler üzerinde yoğunlaştığı araştırılmaktadır.

Çalışmamız kapsamında sosyal bilimler, temel bilimler, mühendislik, sanat ve beşeri bilimler olmak üzere dört alan belirlenmiştir. Her bir alan içinden dört ayrı disiplin çalışmamıza dâhil edilmiştir. Bu disiplinler sosyal bilimler için ekonomi, psikoloji, sosyoloji ve tarih; temel bilimler için biyoloji, istatistik, kimya ve matematik; mühendislik için bilgisayar mühendisliği, elektrik ve elektronik mühendisliği, fizik mühendisliği ve kimya mühendisliği; sanat ve beşeri bilimler için ise felsefe, İngiliz dili ve edebiyatı, resim ve seramik şeklinde saptanmıştır.

Çalışmanınverileriatıfanalizitekniğindenyararlanılaraktoplanmışvedeğerlendirilmiştir. Öncelikle Hacettepe Üniversitesinde tezlerin yapıldığı ilk yıl olan 1968 yılından 2007 yılına kadar 40 yıllık sürede yapılmış olan 3520 tezin bibliyografik künyeleri elde edilmiştir.** Bu evren içinden \%11,1 örnekleme oranı ve tabakalara göre ağırlıklandırma yapılarak 391 tez örneklem grubu olarak belirlenmiştir. Tezlere ilişkin yapılan tabakalı örnekleme işleminde dağılım hem onar yıllık dönemler, hem disiplinler, hem de tez türü (yüksek lisans ya da doktora tezi) dikkate alınarak gerçekleştirilmiştir. Tablo 1'de dönemler itibariyle hangi bölümden kaç tezin örnekleme alındığı bilgisi sunulmaktadır.

\footnotetext{
* Bibliyografik künyelerin elde edilmesi işleminde kütüphane kataloğundan yararlanılmıştır. Kimi durumlarda katalogda yer alan bibliyografik bilgiler ile tezdeki bilgilerin aynı olmadığı ortaya çıkmıştır. Bu ve benzeri durumlara yönelik olarak tez üzerindeki bilgiler esas alınmış ve gerekli düzeltmeler kayıtlarımızda yapılmıştır.
} 
Tablo 1. Onar Yıllık Dönemler ve Disiplinlere Göre Yapılan Tezler ve Örneklem Alınan Tez Sayıları

\begin{tabular}{l|cc|cc|cc|cc|cc}
\hline Bölüm & \multicolumn{2}{|c|}{$\mathbf{1 9 6 8 - 1 9 7 7}$} & \multicolumn{2}{|c|}{$\mathbf{1 9 7 8 - 1 9 8 7}$} & $\mathbf{1 9 8 8 - 1 9 9 7}$ & $\mathbf{1 9 9 8 - 2 0 0 7}$ & \multicolumn{2}{|c}{ Toplam } \\
\hline Kitle / Örneklem & $\mathbf{N}$ & $\mathbf{n}$ & $\mathbf{N}$ & $\mathbf{n}$ & $\mathbf{N}$ & $\mathbf{n}$ & $\mathbf{N}$ & $\mathbf{n}$ & $\mathbf{N}$ & $\mathbf{n}$ \\
\hline Psikoloji & 9 & 1 & 32 & 4 & 47 & 5 & 82 & 9 & 170 & 19 \\
Sosyoloji & 12 & 2 & 23 & 3 & 90 & 10 & 119 & 13 & 244 & 28 \\
Tarih & 5 & 1 & 50 & 6 & 130 & 13 & 218 & 25 & 403 & 45 \\
Ekonomi & 1 & 0 & 7 & 1 & 14 & 2 & 1 & 0 & 23 & 3 \\
Istatistik & 12 & 1 & 37 & 4 & 71 & 8 & 124 & 14 & 244 & 27 \\
Kimya & 16 & 2 & 76 & 8 & 124 & 14 & 143 & 16 & 359 & 40 \\
Matematik & 6 & 1 & 48 & 5 & 65 & 7 & 142 & 16 & 261 & 29 \\
Biyoloji & 18 & 2 & 51 & 6 & 131 & 15 & 207 & 22 & 407 & 45 \\
Fizik Mühendisliği & 11 & 1 & 54 & 6 & 77 & 8 & 93 & 11 & 235 & 26 \\
Kimya Mühendisliği & 0 & 0 & 44 & 5 & 43 & 5 & 157 & 17 & 244 & 27 \\
Elektrik ve Elektronik Müh. & 0 & 0 & 29 & 3 & 74 & 8 & 167 & 18 & 270 & 29 \\
Bilgisayar Mühendisliği & 0 & 0 & 19 & 2 & 41 & 5 & 54 & 6 & 114 & 13 \\
Felsefe & 5 & 1 & 13 & 1 & 23 & 3 & 49 & 5 & 90 & 10 \\
Ingiliz Dili ve Edebiyatı & 24 & 3 & 28 & 3 & 85 & 10 & 73 & 7 & 210 & 23 \\
Resim & 0 & 0 & 6 & 1 & 75 & 8 & 96 & 11 & 177 & 20 \\
Seramik & 0 & 0 & 1 & 0 & 22 & 2 & 46 & 5 & 69 & 7 \\
\hline Toplam & $\mathbf{1 1 9}$ & $\mathbf{1 5}$ & $\mathbf{5 1 8}$ & $\mathbf{5 8}$ & $\mathbf{1 1 1 2}$ & $\mathbf{1 2 3}$ & $\mathbf{1 7 7 1}$ & $\mathbf{1 9 5}$ & $\mathbf{3 5 2 0}$ & $\mathbf{3 9 1}$ \\
\hline
\end{tabular}

$$
n=\frac{N t^{2} p q}{d^{2}(N-1)+t^{2} p q}
$$

Çalışmamızda örneklem büyüklüğünün belirlenmesi için kullanılan formül aşağıda verilmektedir. Formül 1'deki $\mathrm{N}$ evreni, $\mathrm{n}$ örneklem miktarını, $\mathrm{p}$ incelenecek olayın görülme olasılığını, q incelenecek olayın görülmeme olasılığını, t belirli serbestlik derecesinde ve saptanan yanılma düzeyinde $t$ tablosunda bulunan teorik değeri, $d$ hoşgörü miktarını tanımlamaktadır.

Formül 1'deki değerler yerine konduğunda örnekleme alınması gereken tez sayısı 347 olarak saptanmıştır. Tabakalara göre ağırıklandırma yapıldığında daha fazla sayıda tez (391) örnekleme girmiştir. Tezlere ilişkin yapılan tabakalı örnekleme işleminde dağııım hem disiplinler hem de tez türü (yüksek lisans ya da doktora tezi) dikkate alınarak gerçekleştirilmiştir. 
Çalışma kapsamında ele alınan yıllarda ilk dönem olan 1968-1977 yılları arasında bazı bölümlerde tez yapılmanış olduğu görülmektedir. Bu durum kimya mühendisliği, bilgisayar mühendisliği, elektrik-elektronik mühendisliği gibi mühendislik alanları ile, resim ve seramik gibi güzel sanatlar alanlarının bu dönemde temsil edilmemesine neden olmuştur.

Araştırmamızda dört alan ve 16 disiplinden seçilen 391 tez yıl, sayfa sayısı, atıf sayısı gibi bibliyometrik özelliklerine, bu tezlerde yer alan toplam 29.298 atıf yayın türü, dili, yazar sayısı gibi özelliklerine göre incelenmiş, bu özelliklerin zaman içinde ne gibi farklılıklar gösterdiği araştırılmıştır. Çalışmada ayrıca tezlerde yer alan literatürün dönemler itibariyle yaşlanma hızlarında bir farklılık olup olmadığına bakılmıştır. Bunun için tezlerin tamamlandığı yıl tezlerdeki atıfların yayın yılından çıkarılmış, her bir tez için yararlanılan kaynakların ortanca yaşı hesaplanmıştır. Bazı tezlerdeki kimi atıflarda yayın tarihinin olmamasından dolayı tarih bilgisi olmayan 788 atıf yarı yaşam hesaplanırken değerlendirme dışı bırakılmıştır. Tüm bu verilerin kaydı için bir veri tabanı tasarlanarak tezlere ve atıflara ait veriler bu veri tabanına kaydedilmiştir. Araştırmamızda Ki-Kare, Kruskal-Wallis ve Mann Whitney-U gibi istatistikî testler kullanılmış, atıf analizinden elde edilen verilerin değerlendirilmesinde Microsoft Excel ve Statistical Package for the Social Sciences (SPSS) programlarından yararlanılmıştır.

\section{Bulgular ve Yorum}

Araştırma sonucu eldeedilen bulgulartezlerinatıfsayılarıveatıfyapılankaynaklarınözellikleri olarak ele alıp zaman içinde görülen değişim bu başlıklar altında değerlendirilmiştir.

\section{Dönemlere Göre Tez Atıfları}

Çalışmamızda ilk olarak tezlerdeki atıf yönelimlerinin dönemler itibariyle farklı olup olmadığına bakılmıştır. Tezlerdeki ortalama atıf sayıları onar yıllık dönemlere göre incelendiğinde son on yıllık dönemde ilk on yıllık döneme göre yapılan atıf sayısında iki katın üzerinde bir artış olduğu görülmektedir (bkz. Tablo 2). Elde edilen bulgular tezlerde kullanılan yayın sayısının yıllar geçtikçe arttığını göstermektedir.

Tablo 2. Onar Yıllık Dönemler İtibariyle Ortalama Atıf Sayıları

\begin{tabular}{lcccc}
\hline Dönem & Atıf sayısı & Atıf sayısı (\%) & Tez sayısı & $\begin{array}{c}\text { Ortalama atıf } \\
\text { sayısı }\end{array}$ \\
\hline $1968-1977$ & 546 & 1,9 & 15 & 36,4 \\
$1978-1987$ & 3558 & 12,1 & 58 & 61,3 \\
$1988-1997$ & 8153 & 27,8 & 123 & 66,3 \\
$1998-2007$ & 17.032 & 58,2 & 195 & 87,3 \\
\hline Toplam & 29.289 & 100,0 & 391 & 74,9 \\
\hline
\end{tabular}


Dönemlere göre atıf sayıları arasındaki farkın istatistiksel açıdan anlamlı olup olmadığını saptamak için Kruskal-Wallis testi yapılmış ve aradaki ilişki anlamlı bulunmuştur $(\mathrm{H}=12,38 \mathrm{~s} . \mathrm{d} .=3, \mathrm{p}<.05)$. Sıralı ortalamalara baktığımızda en büyük ortalama değerine sahip dönem 1998-2007 yıllarını kapsayan dördüncü dönemdir. Dördüncü dönem bir önceki dönem ile karşılaştırıldığında tez başına düşen ortalama atıf sayısı bakımından \%32'lik bir artışa sahiptir. Ortalama atıf sayısı bakımından ilk dönem ile dördüncü dönem arasında ise neredeyse 2,5 katlık bir fark bulunmaktadır $(\mathrm{H}=3,795$ s.d. $=2, p=0.150)$.

Elde ettiğimiz sonuçları ikili olarak dönemler arasındaki farkı ortaya koyabilmek için Mann Whitney-U testi ile de sınadığımızda Kruskal-Wallis testi ile önceden elde edilen sonucun desteklendiğini görmekteyiz. Mann Whitney-U testine göre birinci ve dördüncü dönem ile üçüncü ve dördüncü dönem arasında anlamlı bir fark olduğu görülmektedir $(P<0,05)$. Diğer dönemler arasında ise anlamlı bir fark bulunmamıştır $(P>0,05)$.

Ortalama atıf sayısı değerlendirildiğinde dönemler arasında ortaya çıkan farklıığın yıllara da yansıdığı ve her geçen yıl tezlerde yararlanılan kaynak sayısının artma eğilimi gösterdiği görülmektedir (bkz. Şekil 1). Bu artışta genel olarak literatüre erişim olanaklarındaki iyileşmenin önemli rolü olduğu söylenebilir.

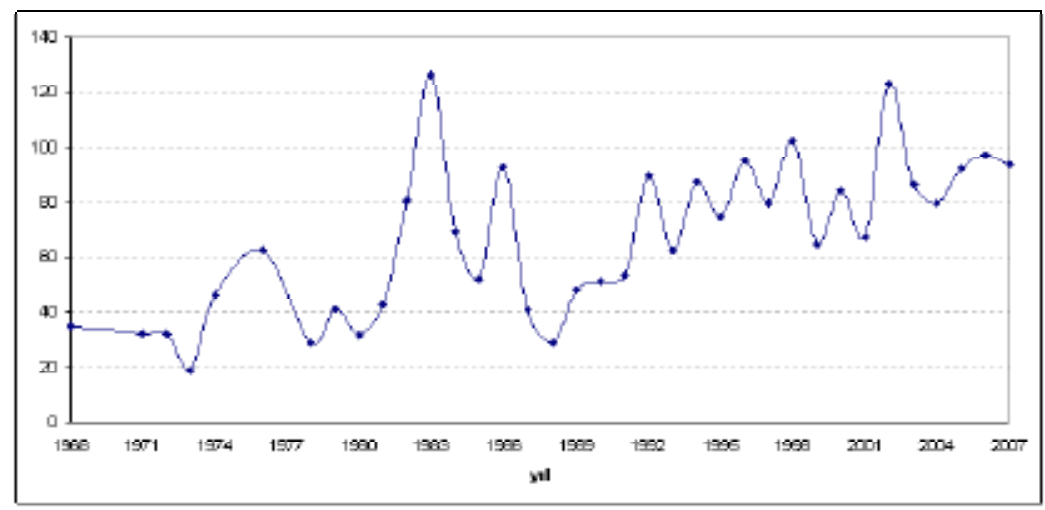

Şekil 1. Tezlerdeki Ortalama Atıf SayılarınınYıllara Göre Dağılımı

\section{Dönemler İtibariyle Kullanılan Yayın Türlerindeki Değişim}

Araştırmamızda 40 yıllık zaman dilimi içinde onar yıllık dönemler halinde incelediğimiz tezlerden ilk dönem olan 1968-1977 yılları arasında bazı disiplinlerde tez olmaması veya tez sayısının az olması bu dönemlere ilişkin olarak alınan örneklem sayısının az olmasında ve temsil oranlarında etkili olmuştur. Genel olarak dönemler itibariyle tezlerde atıf yapılan yayın türleri incelendiğinde dönemler arasında çok fazla bir farklııı olmadığı 
gözlenmektedir. İlk dönem itibariyle dergilere yapılan atıfların kitaplara yapılan atıflardan fazla olduğu saptanmış, diğer dönemler için kitapların dergilerden daha fazla tercih edildiği görülmüştür (bkz. Tablo 3).

Tablo 3. Dönemler İtibariyle Tezlerde Atıf Yapılan Yayın Türleri

\begin{tabular}{|c|c|c|c|c|c|c|c|c|c|c|}
\hline \multirow{2}{*}{ Yayın Türü } & \multicolumn{2}{|c|}{$1968-1977$} & \multicolumn{2}{|c|}{ 1978-1987 } & \multicolumn{2}{|c|}{ 1988-1997 } & \multicolumn{2}{|c|}{$1998-2007$} & \multicolumn{2}{|c|}{ Toplam } \\
\hline & $\mathbf{N}$ & $\%$ & $\mathbf{N}$ & $\%$ & $\mathbf{N}$ & $\%$ & $\mathbf{N}$ & $\%$ & $\mathbf{N}$ & $\%$ \\
\hline Kitap & 246 & 45.1 & 1689 & 47.5 & 4285 & 52.6 & 7826 & 45.9 & 14046 & 48 \\
\hline Dergi & 288 & 52.7 & 1428 & 40.1 & 3057 & 37.5 & 7563 & 44.4 & 12336 & 42.1 \\
\hline Tez & 2 & 0.4 & 53 & 1.5 & 92 & 1.1 & 340 & 2 & 487 & 1.7 \\
\hline E-Yayın & - & - & - & - & - & - & 322 & 1.9 & 322 & 1.1 \\
\hline Bildiri & 2 & 0.4 & 189 & 5.3 & 267 & 3.3 & 461 & 2.7 & 919 & 3.1 \\
\hline Diğer & 8 & 1.5 & 199 & 5.6 & 452 & 5.5 & 520 & 3.1 & 1179 & 4 \\
\hline Toplam & 546 & 100.1 & 3558 & 100,0 & 8153 & 100,0 & 17032 & 100,0 & 29289 & 100,0 \\
\hline
\end{tabular}

Not: Yuvarlama hatasından dolayı toplam yüzdesi \%100'den farklıdır.

Tüm alanlarda en fazla kullanılan kaynak türleri olarak dergi ve kitapların her dönemde önde olduğu görülmektedir. Bu iki kaynağın dönemlere göre kullanımında alanlar arasında ne gibi bir farklılık olduğuna yakından bakmakta yarar vardır. Burada dikkati çeken nokta son dönem itibariyle 1978-1987 ve 1988-1997 arasını içeren dönemlere kıyasla dergi kullanımı ile kitap kullanımı arasındaki oran farkııı̆ının azalış göstermesidir. Son on yıllık dönemde tezlerde dergilere yapılan atıf sayısı neredeyse kitaplara yapılan atıf sayısı kadardır. Bununla birlikte dergi kullanımında zaman içinde bazı alanlarda artış olmasına rağmen bazı alanlarda önemli bir değişimin olmadığı görülmektedir. Örneğin mühendislik ve temel bilimler tezlerinde dergilere yapılan atıflar her dönem sanat ve beşeri bilimler ile sosyal bilimler tezlerinde dergilere yapılan atıflardan fazladır (bkz. Şekil 2).

Kitaplara yapılan atıfların oranı sosyal bilimler ve mühendislikte zaman içinde azalış gösterirken, temel bilimler ile sanat ve beşeri bilimlerde dönemsel olarak dalgalanma olduğu saptanmıştır. Son dönem itibariyle sosyal bilimler ve mühendislik alanlarında kitaplara yapılan atıfların azalmasında bu alanlarda dergilerden yararlanma düzeyinin artması ve mühendislikte elektronik yayınların kullanımına ağırlık verilmesi önemli role sahiptir (bkz. Şekil 2).

Elektronik kaynakların bilimsel iletişimde kullanımı son yıllarda artış göstermektedir. Özellikle açık erişim arşivlerinin yaygınlaşması, araştırmacıların yayınlarını kişisel Web sitelerinde yayımlamaya başlamaları ve bazı bilgilerin sadece elektronik ortamlarda sunulması son dönemde elektronik yayınlara yapılan atıfların belli bir düzeye gelmesine neden olmuştur. 


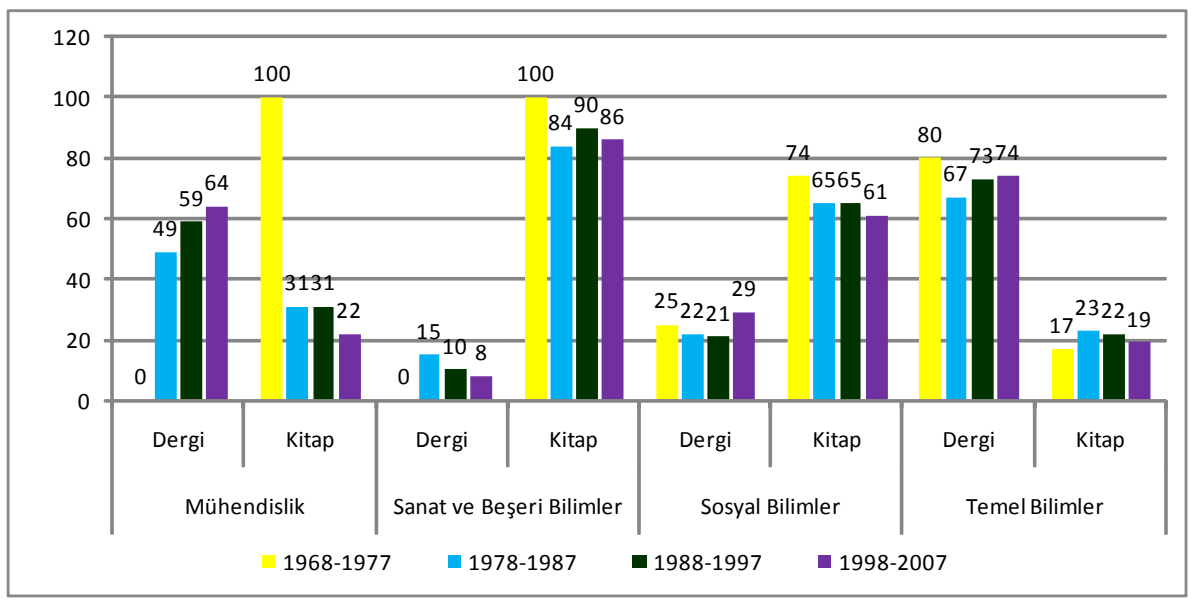

Şekil 2. Dönemler İtibariyle Dergilere ve Kitaplara Yapılan Atıfların Oranı

Çalışmamız kapsamında atıf yapılan yayın türleri arasında elektronik kaynak oranının yıllara göre dalgalı bir seyir izlediği görülmektedir (bkz. Şekil 3). Bununla birlikte son beş yıl (2003-2007) göz önünde bulundurulduğunda elektronik yayınlara yapılan atıfların ortalama \%3 düzeyinde olduğu saptanmıştır. Yıllar ilerledikçe elektronik yayınların kullanımının artacağı ve dolayısıyla bu kaynaklara araştırmalarda daha fazla atıf yapılacağı düşünülmektedir.

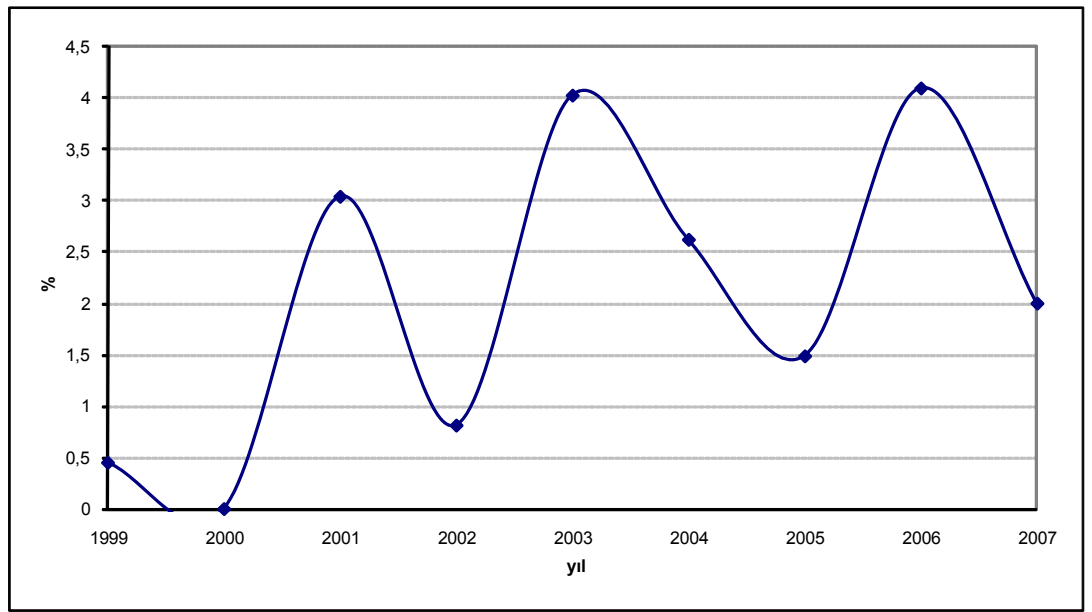

Şekil 3. Elektronik Yayınlara Yapılan Atıfların Yıllara Göre Oranı 
Araştırmamıza konu olan alanlar içindeki disiplinlerin homojen olmaması nedeniyle dönemlere göre incelemenin yanı sıra disiplinlere göre de değerlendirme yapılmıştır. Atıf yapılan kaynak türlerinin bir alan içindeki farklı disiplinlerde değişiklilik gösterebildiği bilinmektedir. Bu nedenle dönemsel olarak karşılaştırmaların sağlıklı yapılabilmesi için alan ve disiplin bazlı değerlendirmelere gereksinim duyulmaktadır.

\section{Sosyal Bilimlerdeki Disiplinler}

Sosyal bilimler alanında her dönem kitap kullanımının dergi kullanımından fazla olduğu görülmektedir (bkz. Tablo 4). Zaman içinde kitaplara yapılan atıf oranı azalsa da kitaplar en fazla kullanılan kaynak olma özelliğini korumaktadır. Tez ve bildiri kullanım oranları ise zaman içinde artış göstermesine rağmen düşük düzeydedir.

Tablo 4. Sosyal Bilim Tezlerinde Atıf Yapılan Yayın Türleri

\begin{tabular}{l|cc|cc|cc|cc|cc}
\hline \multirow{2}{*}{ Yayın Türü } & \multicolumn{2}{|c|}{$\mathbf{1 9 6 8 - 1 9 7 7}$} & \multicolumn{2}{|c|}{$\mathbf{1 9 7 8 - 1 9 8 7}$} & \multicolumn{2}{|c|}{$\mathbf{1 9 8 8 - 1 9 9 7}$} & \multicolumn{2}{|c|}{$\mathbf{1 9 9 8 - 2 0 0 7}$} & \multicolumn{2}{|c}{ Toplam } \\
\cline { 2 - 12 } & $\mathbf{N}$ & $\mathbf{\%}$ & $\mathbf{N}$ & $\mathbf{\%}$ & $\mathbf{N}$ & $\mathbf{\%}$ & $\mathbf{N}$ & $\mathbf{\%}$ & $\mathbf{N}$ & $\mathbf{\%}$ \\
\hline Kitap & 122 & 73.9 & 979 & 65.2 & 2559 & 65 & 4961 & 60.9 & 8621 & 62.7 \\
Dergi & 41 & 24.8 & 323 & 21.5 & 809 & 20.6 & 2322 & 28.5 & 3495 & 25.4 \\
Tez & - & - & 18 & 1.2 & 34 & 0.9 & 137 & 1.7 & 189 & 1.4 \\
E-Yayın & - & - & - & - & - & - & 97 & 1.2 & 97 & 0.7 \\
Bildiri & 1 & 0.6 & 46 & 3.1 & 169 & 4.3 & 254 & 3.1 & 470 & 3.4 \\
Diğer & 1 & 0.6 & 136 & 9.1 & 363 & 9.2 & 370 & 4.5 & 870 & 6.3 \\
\hline Toplam & 165 & 99.9 & 1502 & 100.1 & 3934 & 100,0 & 8141 & 99.9 & 13742 & 99.9 \\
\hline
\end{tabular}

Not: Yuvarlama hatasından dolayı toplam yüzdesi \%100’den farklıdır.

Sosyal bilimlerde disiplinler ayrı ayrı dönemlere göre incelendiğinde, psikolojide dergi kullanımının diğer disiplinlere göre daha fazla ve zamanla artış gösterdiği görülmektedir. Sosyoloji, tarih ve ekonomi için ise dergilere yapılan atıfların psikolojiyle kıyaslandığında oldukça az olduğu saptanmıştır. Dönemler itibariyle sosyolojide dergilere ve kitaplara verilen önem fazla bir değişiklik göstermemektedir. Tarih tezlerinde dönemler itibariyle kitap ve dergilere yapılan atıflar sosyoloji tezleriyle benzerlik arz etmektedir. Örneğin son dönem itibariyle sosyoloji tezlerinde kitaplara yapılan atıfların oranı $\% 69$, dergilere yapılan atıfların oranı \%19 iken; tarih tezlerinde bu oranlar sırasıyla \%67 ve \%23'tür. Tez sayısı az olduğundan ekonomi tezleri için dönemler itibariyle bir değerlendirme yapmak sağlıklı sonuçlar vermeyebilir. Ancak ekonomi disiplininde de sosyoloji ve tarihe benzer bir atıf yönelimi olduğu, kitabın öncelikli tercih edilen kaynak konumunda yer aldığı araştırma sonucundan anlaşılmaktadır (bkz. Şekil 4). 


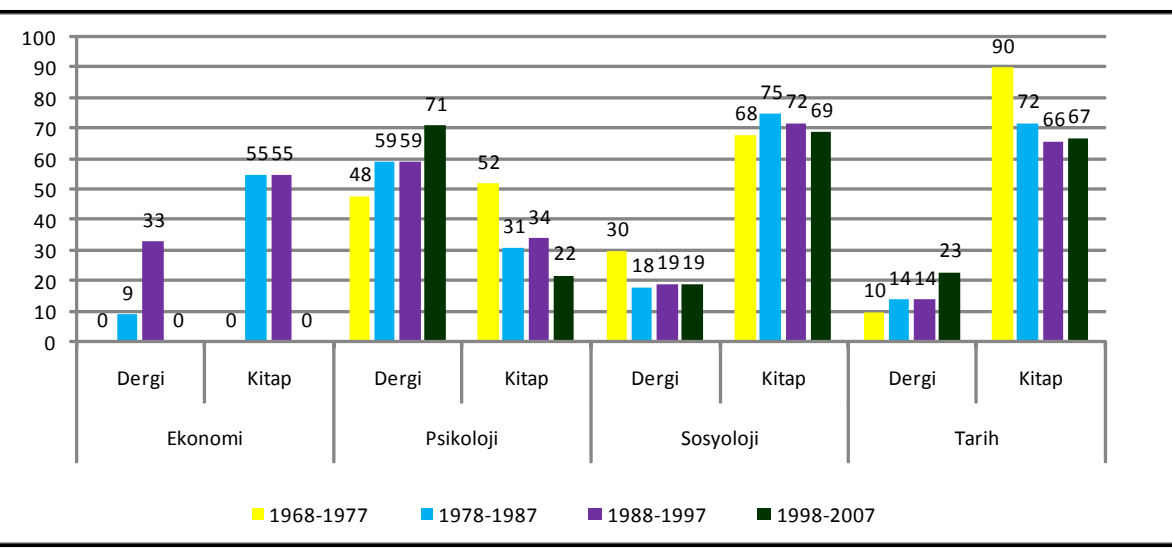

Şekil 4. Sosyal Bilim Tezlerinde Disiplinlere Göre Dönemler İtibariyle Kitaplara ve Dergilere Yapılan Atıfların Oranı

\section{Temel Bilimlerdeki Disiplinler}

Dönemler açısından ele aldığımızda temel bilimlerde sosyal bilimlerin aksine her dönemde dergilere atıf oranının diğer kaynaklardan fazla olduğu görülmektedir. Son iki dönemde dergi kullanım oranları birbirine yakındır. Kitaplara yapılan atıfların oranında ise özellikle son üç dönemde önemli bir fark olmadığı anlaşılmaktadır. Elektronik yayınların son dönemde atıf aldığı ve "diğer" başlığı altında toplanan kaynakların kullanım oranlarının düşük olduğu genel değerlendirmeden anlaşılmaktadır. Son dönem itibariyle kitap, dergi, tez, e-yayın ve bildiri dışında kalan yayın türlerine yapılan atıflar oldukça azalmıştır. 19781987 yılları arasında yapılan tezlerde "diğer" başığı altında sınıflanan atıflar o dönemdeki toplam atıfların \%3,4'ünü oluştururken, son dönemde bu oran \%1,4'e gerilemiştir (bkz. Tablo 5).

Temel bilimlerdeki disiplinler arasında biyoloji ve kimyada dergilere yapılan atıflar oldukça yüksek oranlara sahiptir. Dönemlere göre dergilere yapılan atıfların oranı biyoloji tezlerinde $\% 70$ ile $\% 90$ arasında, kimya tezlerinde $\% 71$ ile $\% 83$ arasında değişmektedir. Oysa ki dergilere yapılan atıfların oranının istatistikte \%48'e (1988-1997), matematikte \%45’e (1978-1987) düştüğü dönemler olduğu saptanmıştır (bkz. Şekil 5). 
Tablo 5. Temel Bilim Tezlerinde Atıf Yapılan Yayın Türleri

\begin{tabular}{l|cc|cc|cc|cc|cc}
\hline Yayın Türü & \multicolumn{2}{|c|}{$\mathbf{1 9 6 8 - 1 9 7 7}$} & \multicolumn{2}{|c|}{$\mathbf{1 9 7 8 - 1 9 8 7}$} & \multicolumn{2}{|c|}{$\mathbf{1 9 8 8 - 1 9 9 7}$} & $\mathbf{1 9 9 8 - 2 0 0 7}$ & \multicolumn{2}{|c}{ Toplam } \\
\cline { 2 - 10 } & $\mathbf{N}$ & $\%$ & $\mathbf{N}$ & $\mathbf{\%}$ & $\mathbf{N}$ & $\mathbf{\%}$ & $\mathbf{N}$ & $\%$ & $\mathbf{N}$ & $\%$ \\
\hline Kitap & 51 & 16.6 & 262 & 22.6 & 430 & 21.5 & 904 & 19.3 & 1647 & 20.2 \\
Dergi & 247 & 80.2 & 777 & 67 & 1453 & 72.5 & 3463 & 73.9 & 5940 & 72.8 \\
Tez & 2 & 0.6 & 16 & 1.4 & 34 & 1.7 & 118 & 2.5 & 170 & 2.1 \\
E-Yayın & - & - & - & - & - & - & 67 & 1.4 & 67 & 0.8 \\
Bildiri & 1 & 0.3 & 65 & 5.6 & 29 & 1.4 & 70 & 1.5 & 165 & 2 \\
Diğer & 7 & 2.3 & 39 & 3.4 & 58 & 2.9 & 65 & 1.4 & 169 & 2.1 \\
\hline Toplam & 308 & 100,0 & 1159 & 100,0 & 2004 & 100,0 & 4687 & 100,0 & 8158 & 100,0 \\
\hline
\end{tabular}

Not: Yuvarlama hatasından dolayı toplam yüzdesi \%100'den farklıdır.

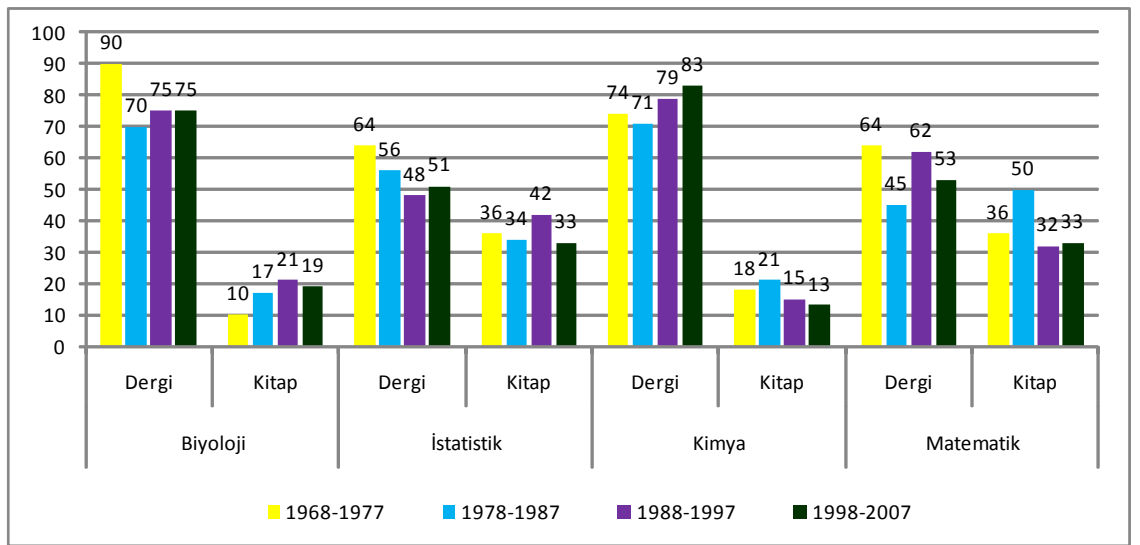

Şekil 5. Temel Bilim Tezlerinde Disiplinlere Göre Dönemler İtibariyle Kitaplara ve Dergilere Yapılan Atıfların Oranı

Bazı dönemler için istatistik ve matematik tezlerinde kitaplara yapılan atıfların dergilere yapılan atıflara yakın olduğu görülmektedir. Hatta 1978-1987 arasında tamamlanan matematik tezlerinde kitaplara yapılan atıflar (\%50) dergilere yapılan atıflardan (\%45) daha fazladır. Bulgular temel bilimlere yönelik koleksiyon geliştirirken özellikle istatistik ve matematik disiplinlerinde çekirdek koleksiyon içinde mutlaka kitaplara yer verilmesi gerektiğini ortaya çıkarmaktadır. 


\section{Mühendislikteki Disiplinler}

Mühendislikte 1968-1977 yılları arasında fizik mühendisliği dışında herhangi bir tez yapılmadığı için değerlendirmeler üç dönem üzerinden gerçekleştirilmektedir. Dönemler itibariyle mühendislik tezlerindeki dergi kullanımında bir artış olduğu saptanmıştır. 19781987 yılları arasında yapılan tezlerdeki atıfların \%48,9'unu dergiler oluştururken, 19881997 yılları arasında yapılan tezlerde bu oran \%59,2'ye, 1998-2007 yılları arasına ait tezlerde ise \%63,6'ya çıkmıştır. Dergilere yönelik bu artışa karşılık mühendislik açısından son derece önemli bir bilimsel iletişim ortamı olduğu kabul edilen bildirilere yapılan atıfların oranı dönemler itibariyle azalmaktadır. 1978-1987 yılları arasında yapılan tezlerde bildirilere \%13,5 oranında atıf yapılırken, bu oran 1988-1997 arasındaki tezler için \%5,9'a, 19982007 yılları arasındaki tezler için ise \%4,8'e gerilemiştir (bkz. Tablo 6). Söz konusu gerileme yıllar içinde bildirilere verilen önemin azaldığına işaret etmektedir. Ancak, atıf yapılan yayın türleri arasında bildirilerin dergi ve kitaplardan sonra en sık atıf yapılan üçüncü kaynak türü olması her dönem için geçerlidir.

Tablo 6. Mühendislik Tezlerinde Atıf Yapılan Yayın Türleri

\begin{tabular}{|c|c|c|c|c|c|c|c|c|c|c|}
\hline \multirow[t]{2}{*}{ Yayın Türü } & \multicolumn{2}{|c|}{ 1968-1977 } & \multicolumn{2}{|c|}{ 1978-1987 } & \multicolumn{2}{|c|}{ 1988-1997 } & \multicolumn{2}{|c|}{ 1998-2007 } & \multicolumn{2}{|c|}{ Toplam } \\
\hline & $\mathbf{N}$ & $\%$ & $\mathbf{N}$ & $\%$ & $\mathbf{N}$ & $\%$ & $\mathbf{N}$ & $\%$ & $\mathbf{N}$ & $\%$ \\
\hline Kitap & - & - & 175 & 30.7 & 358 & 30.5 & 574 & 22.1 & 1117 & 25.7 \\
\hline Dergi & - & - & 279 & 48.9 & 695 & 59.2 & 1651 & 63.6 & 2625 & 60.3 \\
\hline Tez & - & - & 15 & 2.6 & 22 & 1.9 & 72 & 2.8 & 109 & 2.5 \\
\hline E-Yayın & - & - & - & - & - & - & 97 & 3.7 & 97 & 2.2 \\
\hline Bildiri & - & - & 77 & 13.5 & 69 & 5.9 & 125 & 4.8 & 271 & 6.2 \\
\hline Diğer & - & - & 24 & 4.2 & 30 & 2.6 & 78 & 3 & 132 & 3 \\
\hline Toplam & 10 & 100,0 & 570 & 99.9 & 1174 & 100.1 & 2597 & 100,0 & 4351 & 99.9 \\
\hline
\end{tabular}

Not: Yuvarlama hatasından dolayı toplam yüzdesi \%100'den farklıdır.

Disiplin bazında incelendiğinde dergilerdeki bu artışın özellikle kimya mühendisliğinde gerçekleştiği ve geneli etkilediği söylenebilir. Elektrik ve elektronik mühendisliği ile bilgisayar mühendisliği disiplinlerinde son dönem ile bir önceki dönem kıyaslandığında dergilere yapılan atıfların azaldığı saptanmıştır. Son dönem itibariyle mühendislik alanında dergilere yapılan atıfların en yüksek olduğu disiplin fizik mühendisliğidir. Fizik mühendisliğinde 19982007 yılları arasında tamamlanan tezlerdeki atıf yapılan her beş kaynaktan dördü dergidir (bkz. Şekil 6).

Kitaplara yapılan atıfların bilgisayar mühendisliği dışındaki mühendisliklerde azalma eğiliminde olduğu görülmektedir. Mühendislikte dönemler itibariyle kitaplara yapılan atıflardaki en hızlı düşüş elektrik ve elektronik mühendisliğinde gerçekleşmiştir. 1978-1987 arası yapılan tezlerde atıfların \%67'si kitaplara yapılmışken, bu oran 1988-1997 arasında \%52'ye, 1998-2007 arasında ise \%35’e gerilemiştir (bkz. Şekil 6). 


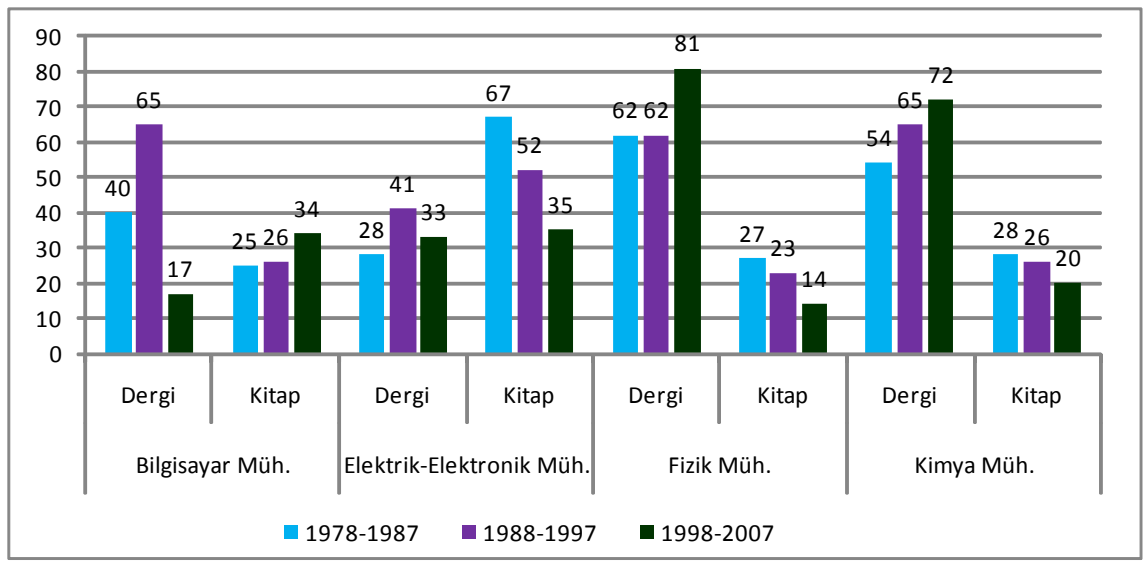

Şekil 6. Mühendislik Tezlerinde Disiplinlere Göre Dönemler İtibariyle Kitaplara Yapılan Atıfların Oranı

\section{Sanat ve Beşeri Bilimlerdeki Disiplinler}

Sanat ve beşeri bilimler alanında yer alan resim ve seramik bölümleri 1968-1977 yıllarından sonra eğitim faaliyetlerine başladıkları için bu yıllara ait herhangi bir tez örneklemde yer almamıştır.

Tablo 7. Sanat ve Beşeri Bilimler Tezlerinde Atıf Yapılan Yayın Türleri

\begin{tabular}{l|cc|cc|cc|cc|cc}
\hline \multirow{2}{*}{ Yayın Türü } & \multicolumn{2}{|c|}{$\mathbf{1 9 6 8 - 1 9 7 7}$} & \multicolumn{2}{|c|}{$\mathbf{1 9 7 8 - 1 9 8 7}$} & \multicolumn{2}{|c|}{$\mathbf{1 9 8 8 - 1 9 9 7}$} & \multicolumn{2}{|c|}{$\mathbf{1 9 9 8 - 2 0 0 7}$} & \multicolumn{2}{|c}{ Toplam } \\
\cline { 2 - 11 } & $\mathbf{N}$ & $\mathbf{\%}$ & $\mathbf{N}$ & $\mathbf{\%}$ & $\mathbf{N}$ & $\mathbf{\%}$ & $\mathbf{N}$ & $\mathbf{\%}$ & $\mathbf{N}$ & $\%$ \\
\hline Kitap & 63 & 100,0 & 273 & 83.5 & 938 & 90.1 & 1387 & 86.3 & 2661 & 87.6 \\
Dergi & - & - & 49 & 15 & 100 & 9.6 & 127 & 7.9 & 276 & 9.1 \\
Tez & - & - & 4 & 1.2 & 2 & 0.2 & 13 & 0.8 & 19 & 0.6 \\
E-Yayın & - & - & - & - & - & - & 61 & 3.8 & 61 & 2 \\
Bildiri & - & - & 1 & 0.3 & - & - & 12 & 0.7 & 13 & 0.4 \\
Diğer & - & - & - & - & 1 & 0.1 & 7 & 0.4 & 8 & 0.3 \\
\hline Toplam & 63 & 100,0 & 327 & 100,0 & 1041 & 100,0 & 1607 & 99.9 & 3038 & 100,0 \\
\hline
\end{tabular}

Not: Yuvarlama hatasından dolayı toplam yüzdesi \%100'den farklıdır.

Genel olarak elde edilen sonuçlardan sanat ve beşeri bilimlerde kitap ağırlıklı kaynak kullanımının yıllara bağlı olarak fazla değişiklik göstermediği anlaşılmaktadır (bkz. Tablo 7). 
Bununla birlikte yüzdesel olarak yapılan değerlendirmede dergilere yönelik atıflarda bir miktar azalma olduğu ortaya çıkmıştır. Kitap ve dergi dışında kaynak kullanım oranları ise çok düşük düzeydedir.

Alan içinde disiplinlerin dergi ve kitap kullanım oranlarına baktığımızda dergi kullanım oranının dönemler itibariyle hiçbir disiplinde \%20'nin üstüne çıkmadığı, felsefede ilk iki dönemde, İngiliz dili ve edebiyatında ise ilk dönemdeki tezlerde sadece kitaplara atıf yapıldığı anlaşılmaktadır. Seramik dışında tüm disiplinlerde kitap kullanımı her dönem \%80'in üzerine çıkmaktadır. Bununla birlikte, seramik tezlerinde son iki dönemdeki kitap kullanım oranı \%79'dur (bkz. Şekil 7).

Ayrı ayrı disiplinlere ilişkin bulgulara bakıldığında, kitaplara yapılan atıfların en düşük olduğu disiplinin seramiktir. Ancak seramikte kitaplara yapılan atıfların en düşük olan dönemde bile \%79'luk orana sahip olması sanat ve beşeri bilimler açısından kitabın önemini göstermesi açısından dikkat çekicidir.

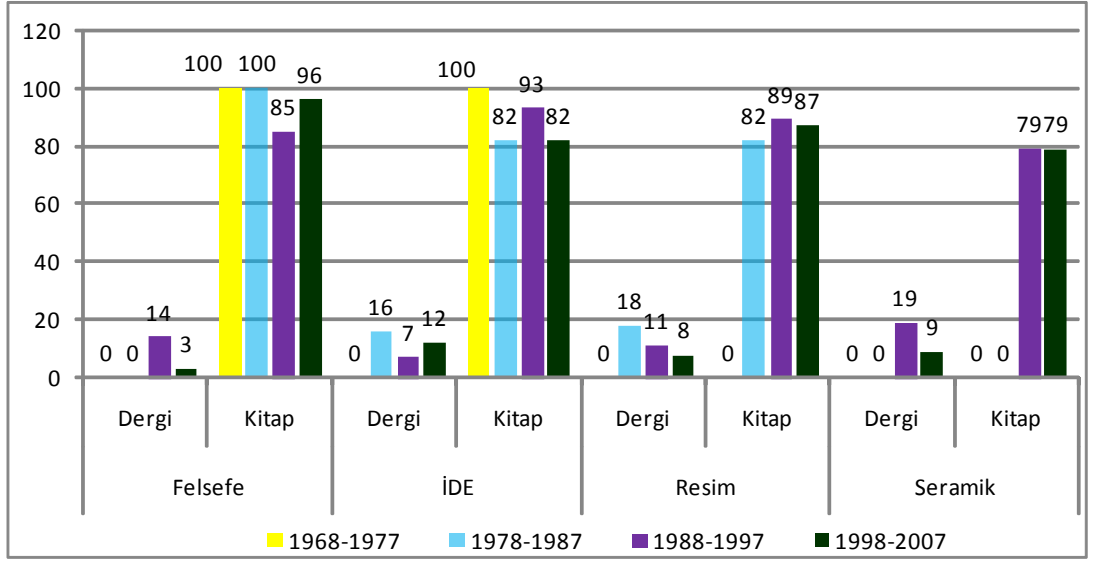

Şekil 7. Sanat ve Beşeri Bilimlerde Disiplinlere Göre Dönemler İtibariyle Kitaplara Ve Dergilere Yapılan Atıfların Oranı

\section{Literatür Eskimesi}

Çalışmamızda dönemler itibariyle alanlara göre yarı yaşam yıllarının değişim gösterip göstermediği incelendiğinde, dönemlere göre yarı yaşam yıllarının farklı olduğu saptanmıştır. Örneğin sosyal bilimlerde 1968-1977 yılları arasını kapsayan dönemdeki yarı yaşam 7,5 yıl iken, 1988-1997 yıllarını kapsayan dönemde iki kat artış göstererek 15 yıla çıkmıştır. Aynı artış mühendislik ve temel bilimlerde de görülmektedir. Sadece sanat ve beşeri bilimlerde dönemler arasında önemli bir farklılık bulunmamaktadır. Bu alanda ilk dönem itibariyle sekiz yıl olan yarı yaşamın daha sonraki üç dönemde de dokuz yıl olduğu saptanmıştır (bkz. Şekil 8). 


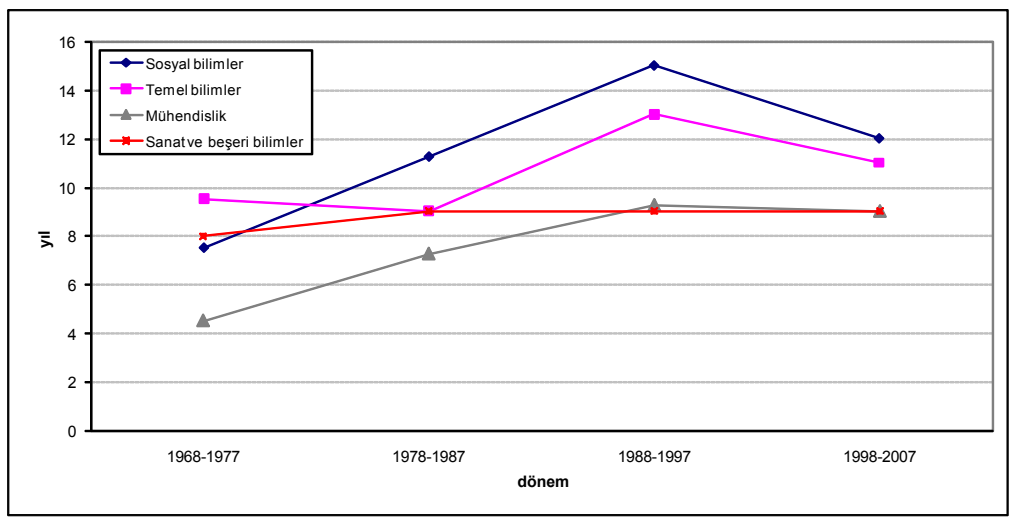

Şekil 8. Dönemler İtibariyle Alanlar Bazında Yarı Yaşam

Çalışmamıza konu olan tezlerdeki atıf sayıları ile yaşlanma arasında istatistiksel olarak anlamlı bir ilişki bulunmuştur (Pearson's $r=0,326, p<0,01$ ). Bir başka ifadeyle, daha fazla kaynak kullanılarak tamamlanan lisansüstü tezlerinin kaynakçalarında yer alan yayınların yarı yaşam yılları daha yüksek bulunmuştur. Daha önce de belirtildiği üzere yıllar geçtikçe tezlerde yararlanılan kaynak sayısı artış göstermektedir. Bu açıdan bakıldığında yıllar geçtikçe atıf sayısındaki artışla birlikte eski literatüre olan talebin yükseldiği görülmektedir.

\section{Atıf Yapılan Kaynakların Dillere Göre Değerlendirilmesi}

Dönemlere göre karşılaştırma yapıldığında kısmen de olsa Türkçe kaynak kullanımında bir artış olduğu buna karşııı İngilizce kaynak kullanımının bir miktar azaldığı ortaya çıkmaktadır. Zamanla Türkçe literatürde görülen artış bunun temel nedeni olarak gösterilebilir. 1968-1977 arasındaki tezlerde atıfların \%16'sı Türkçe kaynaklara yapılırken bu oran son dönemlerde \%40'ların üzerine çıkmıştır (bkz. Şekil 9). Türkçe literatür geliştikçe yerli literatüre yapılan atıfların sayısında görülen bu artışın devam edeceği düşünülmektedir. Ancak İngilizcenin bilim dili olarak yaygın kullanıma sahip olması nedeniyle özellikle evrensel bilgiye talebin fazla olduğu alanlarda İngilizce kaynak kullanımının diğer dillerdeki kaynakların kullanım oranlarından fazla olacağı açıktır.

Dönemler itibariyle tezlerde atıf yapılan kaynakların dillere göre dağılımı alanlar bazında farklılık göstermektedir. Örneğin, sosyal bilimlerde İngilizce kaynakların kullanımı diğer üç alanla karşılaştırıldığında oldukça düşüktür (bkz. Şekil 10). Bu durumun temel nedeni ana dili İngilizce olmayan ülkelerde sosyal bilimler alanında üretilen İngilizce yayınların sayısının az olmasıdır (Denkel, Kağıtçıbaşı, Pak ve Pamuk, 2002, s.1). Doğal olarak bu durum tezlerde yararlanılan kaynaklara da yansımaktadır. Sanat ve beşeri bilimlerde ise İngilizce kaynak kullanımının dönemler itibariyle azalış gösterdiği saptanmıştır. İlk dönem itibariyle \%90'nın üzerinde olan İngilizce kaynak kullanım oranı son dönem itibariyle \%39 düzeyine inmiştir. Özellikle sanat ve beşeri bilimler alanında İngiliz dili ve edebiyatı disiplininin de bulunması nedeniyle bu İngilizce kaynak kulanım oranındaki azalma dikkat çekicidir. 


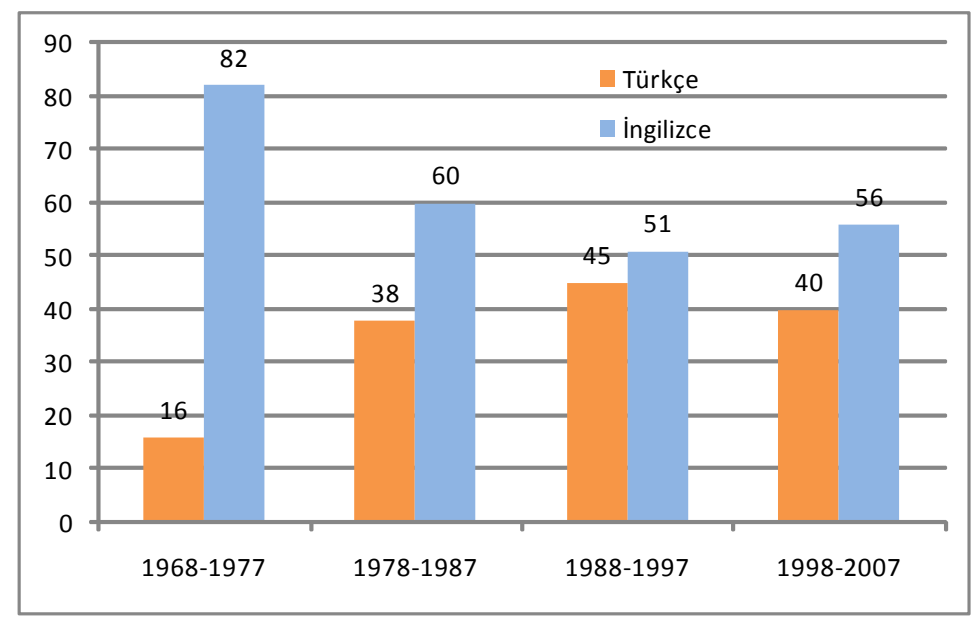

Şekil 9. Dönemler İtibariyle Tezlerde Atıf Yapılan Kaynakların Dillere Göre Dağılımı

Temel bilimler ve mühendislik alanlarında İngilizce kaynak kullanım oranlarının yüksek olduğu ve bu durumun dönemler itibariyle pek fazla bir farklılık göstermediği elde edilen bulgulardan anlaşılmaktadır. Ayrıca bu alanlarda yapılan tezlerde İngilizce dışında kaynak kullanımının oldukça sınırı kaldığı dikkati çekmektedir. Son dönemde mühendislikte İngilizce kaynaklara yapılan atıflar tüm atıfların \%95'ini oluşturmaktadır.

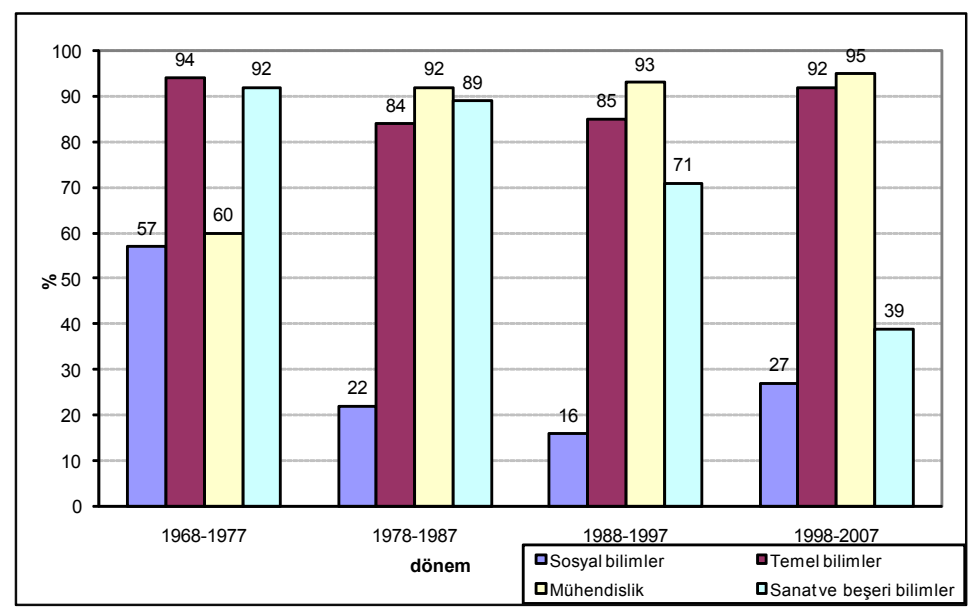

Şekil 10. Dönemler ve Alanlara Göre İngilizce Kaynak Kullanım Oranları 


\section{Atıf Yapılan Kaynakların Yazarlık Durumlarına Göre Değerlendirilmesi}

Yapılan çalışmalarda çok yazarlılık kavramına ilişkin olarak iki temel nokta ön plana çıkmaktadır. Bunlar yıllar içinde çok yazarlı yayın sayısı ile tek yazarlı yayın sayısı arasında bir farklılık bulunup bulunmadığı ve yayın başına düşen ortalama yazar sayısındaki değişimlerdir (Al, 2005, s.32). Bu çalışmada tezlerdeki atıfların çok yazarlı olup olmadığı incelenmiş ve çok yazarlı yayınlara yapılan atıfların dönemlere göre değerlendirilmesi yapılmıştır. Genellikle çok yazarlılığın araştırıldığı çalışmalarda, ya belli bir dergi ya da belli bir konu alınıp yazar analizleri gerçekleştirilmektedir. Bununla birlikte atıf analizi ile de zaman içinde çok yazarlı kaynaklara yapılan atıflar arasında bir farklıık olup olmadığı saptanabilmektedir.

Bulgular Hacettepe Üniversitesinde yapılan tezlerde, atıf yapılan kaynaklara ilişkin olarak çok yazarlı yayın kullanımının tek yazarlı yayın kullanımının oldukça gerisinde kaldığını göstermektedir. Bu durumun dönemler bazında karşılaştırıldığında da fazla bir değişiklik göstermediği saptanmıştır (bkz. Şekil 11). Literatürden farklılık gösteren bu bulgunun ilgili alanlarda yapılacak çalışmalar ile test edilmesi gerekmektedir. Nitekim alanlar ayrı ayrı ele alınıp disiplinlere göre tek ve çok yazarlı eser kullanım oranlarına baktığımızda alanlar arasındaki farklılıklar daha net ortaya çıkmaktadır.

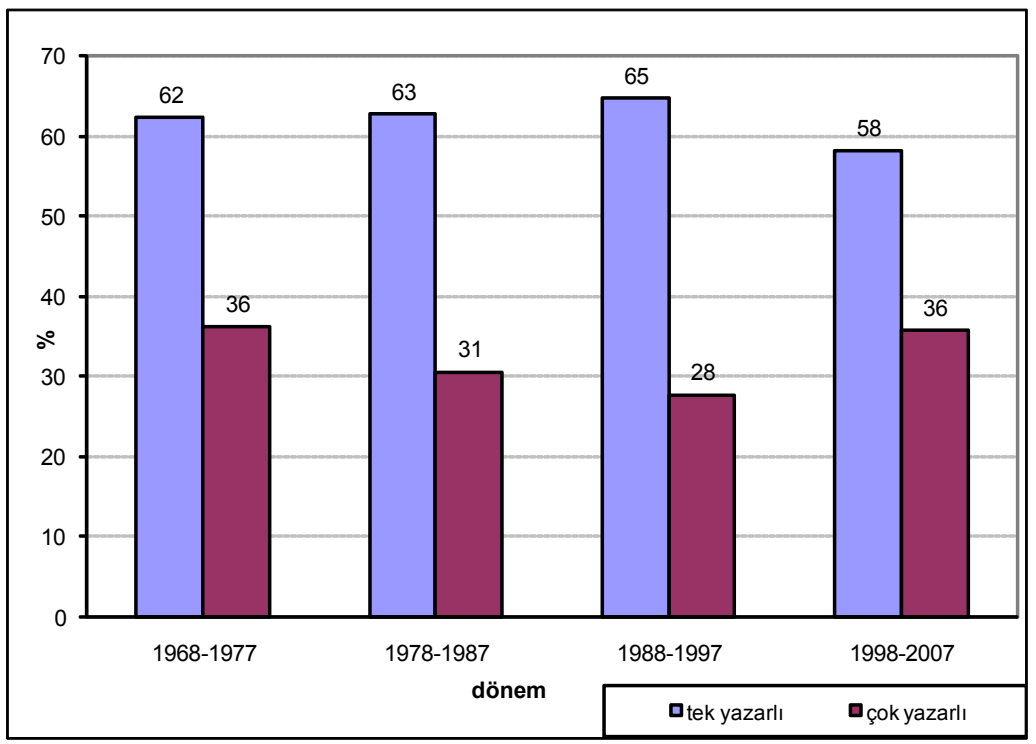

Şekil 11. Dönemler İtibariyle Tezlerde Atıf Yapılan Kaynakların Yazarlık Durumları 
Çok yazarlı yayınlara yapılan atıflar alanlara göre değerlendirildiğinde, temel bilimler ve mühendislikte her dönem diğer alanlardan daha fazla oranda çok yazarlı yayın kullanıldığı görülmektedir. Sanat ve beşeri bilimler ile sosyal bilimlerde çok yazarlı yayınlara yapılan atıflar dönemler itibariyle bir artış göstermezken, temel bilimler ve mühendislikte bu durumun tam tersine giderek artış gösterdiği anlaşılmaktadır. Özellikle son dönem temel bilimler ve mühendisliğin çok yazarlılık açısından atıf oranlarının en yüksek olduğu dönemdir (bkz. Şekil 12).

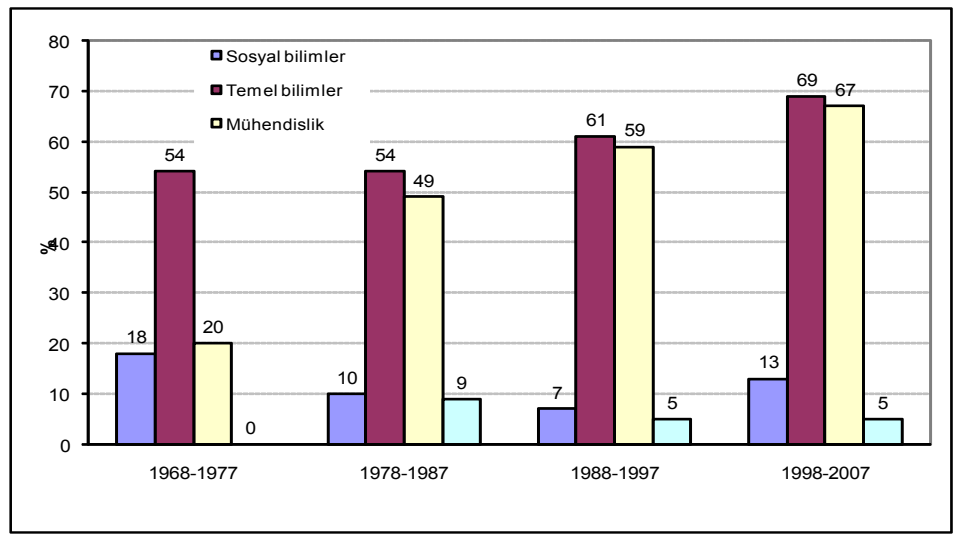

Şekil 12. Dönemler Itibariyle Çok Yazarlı Yayınlara Yapılan Atıflar

\section{Sonuç}

"Tek değişmeyenin değişim" olduğu söylemi birçok platformda dile getirilen bir konudur. Bilimsel ortamın pek çok faktörün etkisiyle hızlı bir değişim yaşadığı, buna bağlı olarak bilimsel iletişimin zamanla değişim gösterdiği bilinmektedir. Disiplinler arasındaki sınırların ortadan kalkmaya başlaması sonucu yaygınlaşan ortak çalışma yapma gereği, hızı bir şekilde sonuca ulaşmanın getirdiği maliyet avantajları, araştırmaların değerlendirilmesinin önemi ve araştırmacıların performanslarının sorgulanmasındaki artış, bilgi ortamlarının çeşitlenmesi, bilgiye erişimde ve paylaşımda yaşanan gelişmeler gibi pek çok etmen bilimsel iletişimin ritüellerini değiştirmektedir.

Bu çalışmada kırk yıllık süreç içinde dört farklı alanda yapılan tezlerde zamanla atıf sayısının arttığı; yayın türü olarak en fazla kitap ve dergilere atıf yapıldığı; kitaplara yapılan atıflarda son zamanlarda bir azalma görüldüğü ancak atıf yapılan yayın türünün disiplinlere göre farklııı gösterdiği; aynı şekilde Türkçe literatür kullanımının ve literatür yaşlanmasının alanlara göre değişim gösterdiği; uluslararası bilimsel iletişimde bilim dili olduğu kabul edilen İngilizcenin kullanımının zaman içinde azalma göstermesine karşın, en fazla kullanılan yayın dili olma özelliğini koruduğu; çok yazarlı yayınlara yapılan atıflarda alanlar arasında fark olmasına rağmen dönemler arasında pek fazla bir farklılık gözlenmediği elde edilen sonuçlardan anlaşılmaktadır. 
Sonuç olarak bilimsel iletişimde zamana bağlı olarak değişimler yaşandığı, ancak bu değişimlerin disiplinlerin özelliklerine göre farklılıklar gösterdiği söylenebilir. Bu nedenle atıf analizi çalışmalarının farklı dönemlerde yeniden yapılması, önceki araştırmaların sonuçlarıyla karşılaştırıması ve kullanıcı davranışlarını inceleyen çalışmalarla desteklenmesi gerekmektedir. Bu tür araştırmalar sonucu elde edilen verilerle bilimsel iletişim sürecini daha yakından tanımak ve ilgili konularda politika geliştirmek olanaklı hale gelecektir.

\section{Kaynakça}

Al, U. (2005). Çok yazarlılı̆ın bilimsel iletişimdeki yeri. M. E. Küçük (Yay. Haz.). Prof. Dr. Nilüfer Tuncer’e Armağan içinde (ss.31-41). Ankara: TKD.

Al, U., Şahiner, M. ve Tonta, Y. (2006). Arts and humanities literature: Bibliometric characteristics of contributions by Turkish authors. Journal of the American Society for Information Science and Technology, 57(8), 1011-1022.

Anderson, K., Sack, J., Krauss, L. ve O'Keefe, L. (2001). Publishing online-only peer-reviewed biomedical literature: Three years of citation, author perception, and usage experience. The Journal of Electronic Publishing, 6(3). 15 Kasım 2008 tarihinde http://quod.lib.umich.edu/cgi/t/text/textidx?c =jep;view=text,rgn=main;idno=3336451.0006.303 adresinden erişildi.

Bates, T., Anić, A., Marušić, M. ve Marušić, A. (2004). Authorship criteria and disclosure of contributions: Comparison of 3 general medical journals with different author contribution forms. JAMA, 292(1), 86-88.

Bauer, K. ve Bakkalbasi, N. (2005). An examination of citation counts in a new scholarly communication environment. D-Lib Magazine, 11(9). 15 Kasım 2008 tarihinde http://dlib.org/dlib/september05/ bauer/09bauer.html adresinden erişildi.

Bhat, S. V. R. ve Kumar, B. T. S. (2008). Web citation behaviour in scholarly electronic journals in the field of library and information science. Webology, 5(2). 15 Kasım 2008 tarihinde http://www.webology. ir/2008/v5n2/a57.html adresinden erişildi.

Borgman, C. L. ve Furner, J. (2002). Scholarly communication and bibliometrics. Annual Review of Information Science and Technology, 36, 3-72.

Carriveau, K. L. (2001). A brief history of e-prints and the opportunities they open for science librarians. C. Schlembach ve W.H. Mischo (Yay.Haz.). Electronic resources and services in scitech libraries içinde (ss.73-82). Mary Binghamton, NY: Haworth Information Press.

Casalini, B. (2003). Journals and monographs: An Italian perspective. LIBER Quarterly, 13, 222-231. $16 \mathrm{Kasım} 2008$ tarihinde http://liber.library.uu.nl/publish/articles/000037/article.pdf adresinden erişildi.

Clarke, B. L. (1964). Multiple authorship trends in scientific papers. Science, 143(3608), 822-824.

Cronin, B. (2001). Hyperauthorship: A postmodern perversion or evidence of a structural shift in scholarly communication practices? Journal of the American Society for Information Science and Technology, 52(7), 558-569. 
Cunningham, S. J. ve Bocock, D. (1995). Obsolescence of computing literature. Scientometrics, 34(2), 255-262.

Davis, P. M. ve Cohen, S. A. (2001). The effect of the Web on undergraduate citation behavior 19961999. Journal of the American Society for Information Science and Technology, 52(4), 309-314.

Denkel, A., Kağıtçıbaşı, Ç., Pak, N. K. ve Pamuk, Ş. (2002). Türkiye'de sosyal bilimlerin uluslararası yayın performansı. Ankara: TÜBA.

Glänzel, W. ve Schoepflin, U. (1995). A bibliometric study on ageing and reception processes of scientific literature. Journal of Information Science, 21(1), 37-53.

Gordon, M. D. (1980). A critical reassessment of inferred relations between multiple authorship, scientific collaboration, the production of papers and their acceptance for publication. Scientometrics, 2(3), 193-201.

Herman, E. (2001). End-users in academia: Meeting the information needs of university researchers in an electronic age: Part 2 Innovative information-accessing opportunities and the researcher: User acceptance of IT-based information resources in academia. Aslib Proceedings, 53(10), 431-457.

Herring, S. D. (2002). Use of electronic resources in scholarly electronic journals: A citation analysis. College and Research Libraries, 63(4), 334-340.

Kushkowski, J. D. (2005). Web citation by graduate students: A comparison of print and electronic theses. Portal: Libraries and the Academy, 5(2), 259-276.

Lindholm-Romantschuk, Y. ve Warner, J. (1996). The role of monographs in scholarly communication: An empirical study of philosophy, sociology and economics. Journal of Documentation, 52, 389404.

Liu, Z. (2003). Trends in transforming scholarly communication and their implications. Information Processing and Management, 39(6), 889-898.

Magner, D. K. (2000). Seeking a radical change in the role of publishing. The Chronicle of Higher Education. 15 Kasım 2008 tarihinde http://chronicle.com/free/v46/i41/41a01601.htm adresinden erişildi.

Sangam, S. L. (1998). Obsolescence of literature in the field of psychology. Scientometrics, 44(1), 3346.

Sylvia, M. J. (1998). Citation analysis as an unobtrusive method for journal collection evaluation using psychology student research bibliographies. Collection Building, 17(1), 20-28.

Thompson, J. W. (2002). The death of the scholarly monograph in the humanities? Citation patterns in literary scholarship. Libri, 52(3), 121-136.

Tonta, Y. (2006). Açık erişim: Bilimsel iletişim ve sosyal bilimlerde süreli yayınclık üzerine etkileri. Sosyal Bilimlerde Süreli Yayıncılık-2006 I. Ulusal Kurultay Bildirileri içinde (ss.23-32). Ankara: ULAKBIM.

Uzun, A. (1998). A scientometric profile of social sciences in Turkey, International Information and Library Review, 30, 169-184.

Vickery, B. C. (2000). Scientific communication in history. Lanham, Md: Scarecrow Press.

Waters, L. (2000). A modest proposal for preventing the books of the members of the MLA from being a burden to their authors, publishers, or audiences. PMLA, 115(3), 315-317. 